\title{
ANALISIS PENGARUH GINI RATIO DAN JUMLAH PENDUDUK TERHADAP TINGKAT KEMISKINAN KABUPATEN/KOTA DI PROVINSI ACEH
}

\author{
M. Saleh ${ }^{1)}$ dan Azka Rizkina ${ }^{2)}$ \\ 1) 2) Fakultas Ekonomi, Universitas Almuslim \\ Email: azkaa_riskina@yahoo.co.id
}

\begin{abstract}
Penelitian ini bertujuan untuk menganalisis pengaruh gini ratio dan jumlah penduduk terhadap kemiskinan kabupaten/kota di Aceh. Dengan menggunakan model panel ARDL. Jenis data yang digunakan adalah data panel dari tahun 2010 sampai tahun 2019 yang mencakup 23 kabupaten/kkota di Aceh. Dengan total sampel sebanyak 230 sampel. Hasil penelitian menunjukkan bahwa gini rasio dan jumlah penduduk berepengaruh terhadap kemiskinan dalam jangka pendek. Akan tetapi tidak berpengaruh dalam jangka panjang.

Kata Kunci : Gini Ratio, Jumlah Penduduk. Kemiskinan, Panel ARDL
\end{abstract}

\section{Pendahuluan}

Kemiskinan merupakan salah satu contoh masalah sosial yang disebabkan oleh faktor ekonomi. Ketidakmampuan untuk memenuhi standar minimum kebutuhan dasar yang meliputi kebutuhan makanan maupun non-makanan. Kemiskinan juga merupakan masalah sosial yang dihadapi oleh pemerintah Indonesia.

Kemiskinan dan ketimpangan merupakan masalah serius dalam suatu perekonomian karena dapat menghambat laju pertumbuhan ekonomi daerah tersebut. Kehadiran kemiskinan dan ketimpangan akan sulit mencapai tujuan dari kebijakan ekonomi yaitu masyarakat memiliki pekerjaan yang merata dan berkualitas (full employment), meningkatkan taraf hidup masyarakat dengan tercapai kesejahteraan yang dicita-citakan (economic growth) dan kestabilan harga dalam sebuah perekonomian suatu daerah (price stability) (Affandi, Zulham, \& Gunawan, 2017).

Menurut Gorman (2009), kesenjangan pendapatan merujuk pada selisih dalam pendapatan antara kalangan berbagai kelompok individual dan rumah tangga dalam perekonomian. Reditribusi pendapatan merujuk pada program pemerintah untuk meratakan perbedaan pendapatan beberapa derajat. Ini melibatkan mengambil uang dari sebagian masyarakat yang relatif kaya dan mengalihkannya kepada masyarakat yang relatif miskin, melalui bantuan publik dan program pemerintah lainnya (Affandi, dkk, 2017)

Penduduk miskin adalah penduduk yang memiliki rata-rata pengeluaran per kapita per bulan di bawah Garis Kemiskinan. "Selama periode Maret 2019 - September 2019, Garis Kemiskinan di Aceh naik sebesar 3,59 persen, yaitu dari Rp486.935 per kapita per bulan menjadi Rp504.414 per kapita per bulan. Sedangkan kabupaten/kota kemiskinan tertinggi di aceh adalah kabupaten Aceh Utara.

Kabupaten Aceh Utara menjadi daerah penduduk miskin terbanyak di Provinsi Aceh dibandingkan dengan 22 kabupaten/kota lainnya di Aceh. Berdasarkan laporan Badan Pusat Statistik, (2020), pada tahun 2019 angka kemiskinan di Kabupaten Aceh Utara mencapai 107.34 ribu jiwa.

Jumlah penduduk juga menjadi indikator penting dari penilaian pembangunan. Apabila dilihat dari jumlah penduduk, Jumlah pendudk di provinsi Aceh mencapai 5.371.532 ribu jiwa dan Kabupaten Aceh Utara merupakan salah salah satu kabuapten sebagai jumlah penduduk masayarakat terbanyak di Provinsi Aceh. Sebagaimana paradigma umum menilai bahwa salah satu ciri negara berkembang dalah jumlah penduduk yang relatif banyak. Akibat bertambahnya volume jumlah penduduk yang banyak akan menyebankan terjadinya tingkat kemiskinan, menyempitnya kesempatan kerja, distribusi pendapatan yang tidak merata, dan lain sebagainya (Atmojo, 2017). 


\section{Kajian Teoritis}

Menurut Todaro \& Smith (2009) kemiskinan absolut merupakan situasi dimana ketidakmampuan atau nyaris tidak mampu untuk memenuhi kebutuhan dasar berupa makanan, pakaian dan tempat tinggal. Jurang kemiskinan adalah jumlah perbedaan antara garis kemiskinan dan tingkat pendapatan aktual semua orang yang hidup dibawah garis tersebut. Gorman (2009) mendefinisikan kemiskinan ialah keadaan seseorang yang kekurangan jumlah yang biasanya atau secara sosial bisa diterima berupa uang atau kepemilikan material lainnya.

Sedangkan menurut Menurut Kuncoro (2006) mengindentifikasikan tiga penyebab terjadinya kemiskinan dipandang dari sisi ekonomi, yaitu pertama kemiskinan muncul karena adanya ketidaksamaan pola kepemilikan sumber daya yang menimbulkan distribusi pendapatan yang timpang. Kedua, kemiskinan muncul akibat perbedaan dalam sumber daya manusia, kualitas sumber daya manusia yang rendah berarti produktivitasnya rendah yang pada giliranya tingkat upahnya rendah. Ketiga, kemiskinan muncul akibat perbedaan akses dalam kepemilikan modal. Dimana ketiga penyebab kemiskinan tersebut bermuara pada teori lingkaran setan kemiskinan (vicious cycle poverty).

Distribusi pendapatan mencerminkan merata atau timpangnya pembagian hasil pembangunan suatu negara di kalangan penduduknya. Tidak meratanya distribusi pendapatan akan memicu ketimpangan pendapatan yang merupakan awal dari munculnya masalah kemiskinan (Hanum, 2018).

Ketimpangan pendapatan adalah distribusi yang tidak proposional dari pendapatan nasional total diantara berbagai rumah tangga dalam negara. Distribusi pendapatan dibedakan menjadi dua jenis yait: distribusi ukuran pendapatan dan distribusi pendapatan fungsional. Distribusi ukuran pendapatan adalah distribusi berdasarkan kelas ukuran orang-orang sebagai contoh, bagian pendapatan total yang diperoleh dari persentase tertentu oarang-orang tertentu tanpa mempersoalkan sumber pendapatannya. Sedangkan distribusi pendapatan fungsional adalah distribusi pendapatan bagi semua faktor produksi tanpa mempersoalkan kepemilikan faktor -faktor itu (Todaro \& Smith, 2009).

Para ekonom pada umumnya membedakan dua ukuran pokok distribusi pendapatan, yang keduanya digunakan untuk tujuan analisis dan kuantitatif. Kedua ukuran tersebut adalah ukuran distribusi pendapatan, yakni besar atau kecilnya bagian pendapatan yang diterima masingmasing orang (biasanya menggunakan metode Kurva Lorenz, Koefisien Gini dan Kriteria Bank Dunia) (Sirojuzilam, 2010).

Dalam Kurva Lorenz, Garis Diagonal OE merupakan garis kemerataan sempurna karena setiap titik pada garis tersebut menunjukkan persentase penduduk yang sama dengan persentase penerimaan pendapatan. Koefisien Gini adalah perbandingan antara luas bidang A dan ruas segitiga OPE. Semakin jauh jarak garis Kurva Lorenz dari garis kemerataan sempurna, semakin tinggi tingkat ketidakmerataannya, dan sebaliknya. Pada kasus ekstrim, jika pendapatan didistribusikan secara merata, semua titik akan terletak pada garis diagonal dan daerah $\mathrm{A}$ akan bernilai nol. Sebaliknya pada ekstrem lain, bila hanya satu pihak saja yang menerima seluruh pendapatan, luas A akan sama dengan luas segitiga sehingga angka koefisien Gininya adalah satu (1). Jadi suatu distribusi pendapatan makin merata jika nilai koefisien Gini mendekati nol (0). Sebaliknya, suatu distribusi pendapatan dikatakan makin tidak merata jika nilai koefisien Gininya mendekati satu. Koefisien Gini (Gini Ratio) adalah salah satu ukuran yang paling sering digunakan untuk mengukur tingkat ketimpangan pendapatan secara menyeluruh. Rumus Koefisien Gini adalah sebagai berikut:

$$
G R=1-\sum_{i=1}^{n} P_{i}\left(F_{i}+F_{i-1}\right)
$$

Dimana: $\mathrm{GR}=$ Koefisien Gini (Gini Ratio) $\mathrm{Pi}=$ Frekuensi penduduk dalam kelas pengeluaran ke-i $\mathrm{Fi}=$ Frekuensi kumulatif dari total pengeluaran dalam kelas pengeluaran ke-i $\mathrm{Fi}-1=$ Frekuensi kumulatif dari total pengeluaran dalam kelas pengeluaran ke-(i-1)

Koefisien Gini didasarkan pada kurva Lorenz, yaitu sebuah kurva pengeluaran kumulatif yang membandingkan distribusi dari suatu variabel tertentu (misalnya pendapatan) dengan distribusi uniform (seragam) yang mewakili persentase kumulatif penduduk.

Teori siklus populasi kemiskinan merupakan argumen utama dari para ekonom yang berpendapat bahwa pertumbuhan penduduk secara cepat menimbulkan berbagai konsekuensi ekonomi yang merugikan. Menurut teori Malthus (dalam Todaro dan Smith, 2004) mengemukakan bahwa pertumbuhan penduduk yang pesat pada suatu negara akan menyebabkan terjadinya kemiskinan kronis, selanjutnya Malthus melukiskan suatu kecenderungan universal bahwa jumlah populasi di suatu negara akan meningkat sangat cepat menurut deret ukur. 
Hubungan antara jumlah penduduk dengan tingkat kemiskinan dapat berpengaruh positif dan dapat juga berpengaruh negatif, hal ini dapat dilihat dari aspek kualitas pertumbuhan penduduk yang mana Pertumbuhan penduduk yang berakibat positif apabila pertumbuhannya dapat mendorong pembangunan ekonomi, artinya kenaikan jumlah penduduk dapat memungkinkan bertambahnya tenaga kerja yang mampu mendorong sektor produksi untuk meningkatkan kegiatan perekonomian. Sedangkan pertumbuhan penduduk dapat berakibat negatif apabila pertumbuhannya dapat menghambat pembangunan ekonomi, artinya pertambahan penduduk tidak dapat meningkatkan produksi sehingga dapat menurunkan kebutuhan konsumsi hasil-hasil produksi. Oleh karena itu, pembangunan ekonomi yang baik adalah jika pertumbuhan penduduk lebih kecil dibandingkan pertumbuhan ekonomi (Agustina, Syechalad, \& Hamzah, 2018)

\section{Metodelogi}

Data yang digunakan dalam penelitian ini adalah data sekunder dalam bentuk panel dari tahun 2010-2019 dan mencakup 23 kabupaten/kota di Aceh. Total sampel dalam penelitian ini adalah sebanyak 230 sampel. Penelitian ini menggunakan model Panel Autoregressive Distributed Lag (ARDL). Penggunaan model panel ARDL dengan asumsi bahwa variabel yang digunakan dalam penelitian ini bersifat dinamis, sehingga model ARDL cocok dalam penelitian ini. Model panel ARDL ini dinyatakan:

$$
\begin{array}{cc}
\Delta \ln C_{j, t}=\alpha_{0 i} & +\sum_{i=1}^{n} \alpha_{1 i} \Delta \ln C_{i, t-1} \\
\sum_{i=1}^{n} \alpha_{2 i} \Delta l n P O P_{i, t-1}+ & \beta_{11} \ln P O P_{j, t-1}
\end{array}+
$$

Di mana C adalah konsumsi dan POP adalah jumlah penduduk, $\alpha_{1}$ sampai dengan $\alpha_{2}$ adalah koefisien jangka pendek, $\beta_{1}$ adalah koefisien jangka panjang, $\mathrm{t}$ adalah tahun yaitu 2010-2019, j adalah wilayah 34 provinsi di Indonesia, i adalah urutan lag, dan u adalah error term

\section{Hasil dan Pembahasan Uji Panel Stasioneritas}

Uji stasioneritas merupakan syarat wajib sebelun estimasi model panel ARDL dilakukan. Hasil uji stasioneritas ini disajikan di Tabel 1. Pengujian stasioneritas pada penelitian ini menggunakan empat pendekatan yakni LLC, IPS, ADF-Fisher dan PP-Fisher dengan individual intercept and trend. Hasil Tabel 1 menjelaskan bahwa setiap variabel terdapat stasioneritas yang berbeda ditingkat level $(\mathrm{I}(0))$ maupun ditingkat first difference (l(1)). Karena ada perbedaan stasioneritas maka model ARDL memenuhi syarat untuk digunakan

\begin{tabular}{|c|c|c|c|c|}
\hline \multicolumn{5}{|c|}{ Individual Intercept and Trend } \\
\hline Variabel & LLC & IPS & $\begin{array}{l}\text { ADF- } \\
\text { Fisher }\end{array}$ & $\begin{array}{c}\text { PP- } \\
\text { Fisher }\end{array}$ \\
\hline GR & $\begin{array}{l}-7.801 \\
(0.000)\end{array}$ & $\begin{array}{l}-0.101 \\
(0.459)\end{array}$ & $\begin{array}{l}52.760 \\
(0.229)\end{array}$ & $\begin{array}{c}118.329 \\
(0.000)\end{array}$ \\
\hline POP & $\begin{array}{l}-3.250 \\
(0.000)\end{array}$ & $\begin{array}{l}-0.103 \\
(0.458)\end{array}$ & $\begin{array}{l}55.489 \\
(0.159)\end{array}$ & $\begin{array}{l}81.189 \\
(0.001)\end{array}$ \\
\hline POV & $\begin{array}{l}-5.349 \\
(0.000)\end{array}$ & $\begin{array}{c}0.827 \\
(0.796)\end{array}$ & $\begin{array}{l}34.322 \\
(0.897)\end{array}$ & $\begin{array}{l}24.581 \\
(0.996)\end{array}$ \\
\hline$\Delta \mathrm{GR}$ & $\begin{array}{c}-20.913 \\
(0.000)\end{array}$ & $\begin{array}{l}-1.971 \\
(0.024)\end{array}$ & $\begin{array}{l}93.117 \\
(0.000)\end{array}$ & $\begin{array}{c}212.122 \\
(0.000)\end{array}$ \\
\hline$\triangle \mathrm{POP}$ & $\begin{array}{c}-15.003 \\
(0.000)\end{array}$ & $\begin{array}{l}-1.111 \\
(0.133)\end{array}$ & $\begin{array}{l}75.642 \\
(0.003)\end{array}$ & $\begin{array}{r}238.686 \\
(0.000)\end{array}$ \\
\hline$\triangle \mathrm{POV}$ & $\begin{array}{l}-3.690 \\
\text { ( ก กกn) }\end{array}$ & $\begin{array}{c}0.776 \\
\text { (n 781) }\end{array}$ & $\begin{array}{l}37.602 \\
(0740)\end{array}$ & $\begin{array}{c}120.024 \\
\text { (ก กnก) }\end{array}$ \\
\hline
\end{tabular}
dalam penelitian ini.

\section{Tabel 1 Uii Root}

\section{Uji Panel Kointegrasi}

Uji kointegrasi dalam penelitian ini menggunakan Panel Cointegration with Predoni dan KAO Based yang bertujuan untuk melihat beberapa variabel terintegrasi pada ordo yang berbeda $\mathrm{I}(0)$ atau $\mathrm{I}(1)$ Badalayan, dkk (2014). Hasil uji panel kointegrasi antara GR, POP dan POV ditingkat signifikansi 5 persen dan 1 persen, sehingga dapat disimpulkan bahwa adanya hubungan jangka pendek ke jangka panjang antara ke tiga variabel.

Tabel 2 Panel kointegrasi

\begin{tabular}{lll}
\hline $\begin{array}{c}\text { Predoni Cointegration } \\
\text { Test }\end{array}$ & \multicolumn{1}{c}{ Statistic } & $\begin{array}{c}\text { Weighted } \\
\text { Statistic }\end{array}$ \\
\hline Panel v-Statistic & -2.395 & -4.930 \\
& $(0.991)$ & $(1.000)$ \\
Panel rho-Statistic & 4.797 & 3.929 \\
Panel PP-Statistic & $(1.000)$ & $(1.000)$ \\
& 5.053 & -1.578 \\
Panel ADF-Statistic & $(1.000)$ & $(0.057)$ \\
& -1.123 & -2.393 \\
Group rho-Statistic & $(0.130)$ & $(0.008)$ \\
& 5.388 & \\
Group PP-Statistic & $(1.000)$ & \\
& -1.947 & \\
Group ADF-Statistic & $(0.025)$ & \\
& -1.905 & \\
& $(0.028)$ & \\
\hline KAO Cointegration Test & t-statistic & \\
\hline ADF & -3.031 & \\
- Sumber: Hasil Pengolahan & $(0.00)$ \\
\end{tabular}

Sumber: Hasil Pengolahan Data, 2021 (diolah)

M. Saleh dan Azka Rizkina | Analisis Pengaruh Gini Ratio dan Jumlah Penduduk.. 


\section{Lag}

Uji lag pada penelitian ini menggunakan Akaike Information Criterion (AIC). Pada dasarnya penelitian melihat nilai yang paling kecil, dan menjelaskan lag optimal menggunakan kriteria AIC dan didapatkan hasil lag sebanyak 1 lag. Oleh karena itu, pemilihan lag yang terbaik dengan meilhat nilai AIC terkecil sehingga lag yang digunakan dalam penelitian ini adalah 1,1 .

\section{Discussions}

Hasil regresi panel ARDL ini memenuhi syarat karena koefisien error corection term berslope negatif dan signifikan. Karena model ini memenuhi syarat maka dapat digunakan sebagai model analisis analisis pengaruh gini ratio \& jumlah penduduk terhadap tingkat kemiskinan kabupaten/kota di aceh seperti yang terdapat di Tabel 3. Koefisien $\mathrm{ECT}_{\mathrm{t}-1}$ menggambarkan bahwa jika terjadi guncangan maka diperlukan waktu selama 1,5 bulan untuk kembali ke posisi keseimbangan sebelum terjadi goncangan. Kondisi ini memperlihatkan adanya upaya yang sangat cepat agar tercapai keseimbangan lagi.

Tabel 3 memperlihatkan bahwa gini ratio berpengaruh secara negatif dan jumlah penduduk berpengaruh secara positif terhadap kemiskinan kabupaten/kota di Aceh dalam jangka pendek. Hal ini dapat dilihat dari aspek kualitas pertumbuhan penduduk yang mana Pertumbuhan penduduk yang berakibat positif apabila pertumbuhannya dapat mendorong pembangunan ekonomi, artinya ketika terjadi peningkatan jumlah penduduk dapat memungkinkan bertambahnya tenaga kerja yang mampu mendorong sektor produksi untuk meningkatkan kegiatan perekonomian. Hasil penelitian ini sejalan dengan penelitian (Hanum, 2018) Akan tetapi tidak berpengaruh dalam jangka panjang terhadap kemiskinan di Indonesia.

Variabel jumlah penduduk tidak berpengaruh secara signifikan terhadap kemiskinan di provinsi Aceh. Dikarenakan jumlah penduduk selalu bertambah untuk setiap tahunnya, sementara kemiskinan cenderung menurun walaupun masih jauh di atas rata-rata kemiskinan nasional. Jadi seiring bertambahnya pertumbuhan penduduk, kondisi perekonomian pun mulai berangsur membaik walaupun sangat lamban (Agustina, dkk , 2018).
Tabel 3 Hasil Regresi Panel ARDL

\begin{tabular}{|c|c|c|c|}
\hline Estimate & Variabel & Coefficient & $\begin{array}{l}\mathrm{t}-\text { Statistic } \\
*\end{array}$ \\
\hline Jangka Panjang & GR & -0.000559 & $\begin{array}{c}-10.88327 \\
(0.000)\end{array}$ \\
\hline (Long Run) & POP & 163.3251 & $\begin{array}{c}9.925034 \\
(0.000)\end{array}$ \\
\hline Jangka Pendek & $\mathrm{C}$ & -3.862631 & $\begin{array}{c}-0.379446 \\
(0.705)\end{array}$ \\
\hline \multirow[t]{3}{*}{ (Short Run) } & $\Delta \mathrm{GR}$ & -0.192968 & $\begin{array}{c}-0.029892 \\
(0.976)\end{array}$ \\
\hline & $\triangle \mathrm{POP}$ & 0.000303 & $\begin{array}{c}0.933809 \\
(0.352)\end{array}$ \\
\hline & ECT(-1) & -0.058618 & $\begin{array}{c}-8.094913 \\
(0.161)\end{array}$ \\
\hline
\end{tabular}

Sumber: Hasil Pengolahan Data, 2021 (diolah)

Note : *) Tingkat Signifikan

\section{Kesimpulan}

Secara keseluruhan hasil temuan menunjukkan bahwa dalam jangka pendek variabel gini rasio dan jumlah penduduk berpengaruh terhadap kemiskinan, sedangkan dalam jangka panjang tidak berpengaruh terhadap kemiskinan kabupaten/kota di Aceh. . Hal ini dapat dilihat dari aspek kualitas pertumbuhan penduduk yang mana Pertumbuhan penduduk yang berakibat positif apabila pertumbuhannya dapat mendorong pembangunan ekonomi, artinya ketika terjadi peningkatan jumlah penduduk dapat memungkinkan bertambahnya tenaga kerja yang mampu mendorong sektor produksi untuk meningkatkan kegiatan perekonomian.

Kelemahan penelitian ini adalah jumlah tahun lebih kecil dibandingkan dengan jumlah kabupaten/kota. Hal ini terjadi karena banyak daerah hasil pemekaran yang tidak memiliki data. Sehingga digunakan tada tahunan. Data kuartalan juga tidak tersedia terutama untuk data penduduk.

Bagi peneliti selanjutnya jika ingin meneliti dibidang yang sama, disarankan untuk menggunakan variabel penelitian yang lebih banyak, sehingga dapat memberikan hasil penelitian yang lebih baik. variabel lain misalnya: pendidikan, IPM serta memperluas sampel misalnya: quartalan atau data bulanan serta bisa memperpanjang range tahun nya. 


\section{Daftar Pustaka}

Affandi. (2017). Pengaruh Anggaran Pendidikan, Tingkat Kemiskinan Dan Ketimpangan Terhadap Produk Domestik Regional Bruto Di Provinsi Aceh. Jurnal Ekonomi Dan Kebijakan Publik Indonesia , 174-191.

Agustina, E., Syechalad, M. N., \& Hamzah, A. (2018). Pengaruh Jumlah Penduduk, Tingkat Pengangguran Dan Tingkat Pendidikan Terhadap Kemiskinan Di Provinsi Aceh . Jurnal Perspektif Ekonomi Darussalam , 265-283.

Atmojo, D. (2017). Analisis Pengaruh Gini Ratio, Indeks Pembangunan Manusia (Ipm), Dan Jumlah Penduduk Terhadap Tingkat Kemiskinan Di Provinsi Jawa Barat Tahun 2012-2016. Jurnal Ekonomi , 1-7.

BPS. (2020). Statistik Keuangan Pemerintah Kabupaten/Kota 2019- 2020. Jakarta: Badan Pusat Statistik

Hanum, N. (2018). Analisis Kemiskinan Dan Ketimpangan Distribusi Pendapatan Di
Kota Langsa (Studi Kasus Gampong Matang Seulimeng). Jurnal Samudra Ekonomika , 157-170.

Gorman, Tom. (2009). The Complete Ideal's Guides : Economics, Terjemahan Sugeng, Sukono, M. Rudi Atmoko Jakarta : Prenada.

Kuncoro, Murdrajat. 2006. "Ekonomi Pembangunan", Penerbit Salemba Empat,Jakarta.

Todaro, Michael P. Dan Smith, Stephen C. 2009. "Pembangunan Ekonomi". Edisi Kesembilan. Jakarta: Erlangga.

Sirojuzilam Dan Mahalli, K. 2010. Regional. Pembangunan, Perencanaan Dan Ekonomi. USU Press. Medan 